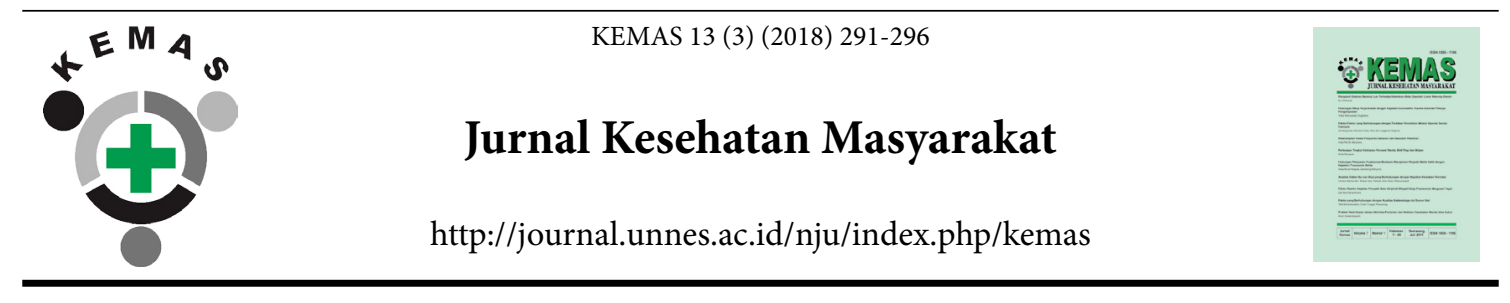

\title{
MIDWIFE'S KNOWLEDGE AND ATTITUDE IN KANGAROO MOTHER CARE TO PREMATURE NEONATAL IN THE PUBLIC HEALTH CENTRE IN BATANG
}

\author{
Ta’adi $^{1 \bowtie}$, Kholifah $^{1}$, Tuti Sukini ${ }^{2}$, Tulus Puji Astuti ${ }^{2}$ \\ ${ }^{1}$ Puskesmas Batang III, Kecamatan Batang \\ ${ }^{2}$ Jurusan Kebidanan Poltekkes Kemenkes Semarang
}

\section{Article Info \\ Article History: \\ Submitted May 2017 \\ Accepted October 2017 \\ Published March 2018 \\ Keywords: \\ Kangaroo Mother Care, \\ Knowledge, Attitude \\ DOI \\ https://doi.org/10.15294/ \\ kemas.v13i3.9644}

\begin{abstract}
One of indicators in the successful health affair in a country is the number of infant mortality rate. Causes of mortality among others are respiratory disorders $37 \%$, prematurity $34 \%$, sepsis $12 \%$, hypothermia7\%, post mature $3 \%$ and congenital defect $1 \%$ and blood defect or icterus $6 \%$. Infant mortality due to hypothermia can be prevented by practical method as an alternative to incubator namely Kangaroo Care Method. The implementation of Kangaroo Care Method must be monitored and evaluated by health care provider especially the midwife. This research was conducted in 2015.The purpose of this research was to find out the correlation between midwives' knowledge and their attitude in implementing Kangaroo Method to premature infant.This research was observasional with design cross sectional approach. The number of population was 65 midwives and as a sample 49 midwives. The data were collected by means of questionnaire. Data analyses used bivariate Spearman rho test. The result of the research showed that 32 midwives (65.3\%) had good knowledge and most of 27 midwives (55.1\%) had positive attitude. It was obtained from Spearman rho test $\rho$ value 0.001 and correlative coefficient (r) 0.696. The conclusion, there was any close correlation between knowledge and attitude of midwives in kangaroo care method.
\end{abstract}

\section{Introduction}

Neonatal mortality rate is among the indicator of national health. Main causes of neonatal death are respiratory distress (37\%), prematurity $(34 \%)$, sepsis (12\%), hypothermia $(7 \%)$, blood abnormality or jaundice (6\%), postmaturity (3\%), and congenital abnormality (1\%). These causes of death often occur in low birth weight (LBW) babies, especially LBW babies with age of pregnancy less than 37 weeks due to asphyxia, respiratory distress, hypothermia, hypoglicemia, breastfeeding problem, infection, jaundice, and bleeding problem (Depkes RI, 2014).
Neonatal death because of hypothermia in LBW babies can be prevented by the use of incubator. The use of incubator becomes a problem in several hospitals due to its limited availability. Furthermore, it needs a high cost and can potentially cause nosocomial infections. Therefore, practical method as an alternative replacement of incubator is needed. Kangaroo method is efficient, effective, and economic because it only requires warmth, nutritional suply, and infection prevention. These requirements can be fulfilled using appropriate technology, which can be performed by the parents (Puspitaningtyas, 2013). 
According to the data in 2015, there are 65 midwives in Batang subdistrict (49 work in a primary health center, 11 work independently, and 5 work in a hospital). Result of research observation from 10 midwives in Batang III primary health center using questionnaire containing kangaroo mother care (PMK), showed only 4 midwives (40\%) knew about KMC and supported it. They said that they never attended training about KMC. This study aimed to understand the relationship between knowledge and attitude of midwives in conducting $\mathrm{KMC}$ in premature neonates in Batang.

\section{Method}

This was an observational study with cross sectional design. We studied independent variable (knowledge) and dependent variable (attitude) using questionnaire or data collection at the same time (Notoatmodjo, 2010).

Population of the study was all 65 midwives in Batang primary health care. Sample collection with purposive sampling provided 49 midwives as study samples. Questionnaire was used as measurement tool. The questionnaire consisted of 30 close-ended question with dichotomous choice.

Knowledge measurement was performed using 20 questions of favourable and unfavourable questions. Answering the right choice from favourable question will be given 1 score, while answering the wrong choice will be given 0 score. Answering the right choice from unfavourable question will be given 0 score, while answering the wrong choice will be given 1 score. Good knowledge category was rewarded if the score was within the range of $76 \%-100 \%$, while sufficient and low knowledge categories will be rewarded if the score was within the range of 56\%-75\% and $<56 \%$, repectively.

Attitude measurement consisted of 10 questions with likert scale. On favourable question, strongly agree, agree, not agree, and strongly disagree will be given score 4 , 3,2 , and 1, respectively. On unfavourable question, strongly agree, agree, not agree, and strongly disagree will be given score 1, 2, 3, and 4 , respectively. Attitude category used cut-off point based on the data distribution of the current study, which was positive if non- normal distributed data $\geq$ median and normal distributed data $\geq$ mean. It was negative if nonnormal distributed data $<$ median and normal distributed data $<$ mean.

Analysis used in this study was univariate analysis for obtaining distribution of midwife's knowledge, percentage of midwife's knowledge, distribution of midwife's attitude, and percentage of midwife's attitude. Bivariate analysis was performed to understand the relationship between knowledge and attitude of the midwives. We used ordinal scale and spearman correlation test with very weak, weak, moderate, and strong correlation strength categories, if the rho was 0.00-0.199, $0.20-0.399,0.40-0.599,0.60-0.799$, and $0.80-$ 1.000 , respectively.

\section{Result and Discussion}

The questions related to variable of knowledge consisted of definitions, purposes, benefits, implementations, durations, types, steps, and KMC monitoring. Recapitulation of the answers from midwives showed 14 midwives (28.6\%) answered the questions regarding the benefits of $\mathrm{KMC}$ incorrectly. The correct answer of the benefits of KMC was as follows: it can stabilize the respiratory of neonates, stabilize temperature of the neonates within $36.5{ }^{\circ} \mathrm{C}-37{ }^{\circ} \mathrm{C}$, and make neonates sleep longer. Regarding implementation of KMC, 12 midwives (24.5\%) answered incorrectly that KMC can be performed in severely sick neonates as in sepsis and respiratory distress. The right answer is KMC can only be performed in neonates with stable condition. In question about who are the provider of KMC, 13 midwives (26.5\%) answered only mother can provide the KMC. In fact, other members of the family (father, grandfather, grandmother, aunt, etc) are allowed to provide the KMC in exchange of the mother. The outfit used in $\mathrm{KMC}$ is also very simple without particular requirements. Triangle shaped fabric, sarong, dance cloth, or sac model fabric can be used to attach the neonates to the KMC provider. Furthermore, the provider of KMC must use loose outfits in order to cover the body of the neonates. In addition, 10 midwives (20.4\%) answered that during the $\mathrm{KMC}$, the mother cannnot move freely. This answer is wrong because during $\mathrm{KMC}$, the mother still can 
Table 1. Distribution of Midwives Knowledge about KMC in Premature Neonates in Batang Primary Health Care in Batang Subdistrict

\begin{tabular}{lll}
\hline Knowledge & Frequency & Percentage (\%) \\
\hline Low & 11 & 22.4 \\
Sufficient & 6 & 12.2 \\
Good & 32 & 65.3 \\
\hline Total & 49 & 100.0 \\
\hline
\end{tabular}

Source: Primary Data, 2015

Table 2. Analysis of Attitude Distribution of Midwives on KMC for Premature Neonates in Batang Primary Health Care, Batang Subdistrict, Batang Regency

\begin{tabular}{llllll}
\hline Variable & Mean & Median & SD & Sig & Min-Max \\
\hline Attitude & 26.10 & 30.00 & 7.933 & 0.005 & $10-40$ \\
\hline
\end{tabular}

Source: Primary Data, 2015

freely move (stand, walk, sit, eat, etc).

Knowledge was categorized into 3 categories as follows: good, sufficient, and low knowledge. According to the table 1, 32 midwives (65.3\%) had good knowledge, 6 midwives had sufficient knowledge (12.2\%), and 11 midwives (22.5\%) had low knowledge.

Knowledge can be affected by internal factors, such as education, occupation, and age. It can also be affected by external factos, such as environment and culture. Knowledge can be obtained from trial, authority, experience, way of thinking, and scientific research (Notoatmodjo, 2010).

Result of the answer toward attitude questions showed that 24 midwives (49.0\%) agreed to implement $\mathrm{KMC}$ on premature neonates because of its benefits on stabilizing neonate's respiration. However, 15 midwives (30.6\%) disagreed to implement KMC. There were 25 midwives (51.0\%) who will performed KMC once the neonates was stabilized, while the other 16 midwives (32.7\%) will performed KMC without waiting for the neonates to be stabilized. Furthermore, 21 midwives (42.9\%) will performed the KMC until the body weight of the neonates become 2500 gram or until neonates feel unconformtable with this method, while 6 midwives (12.2\%) will not.

Twenty six midwives (53.1\%) will implement KMC on neonates still in need of conventional care (incubator). However, 16 midwives (32.7\%) thought that it was unnecessary. Twenty three midwives (46.9\%) will suggest other family member to replace mother to provide $\mathrm{KMC}$, while 4 midwives (8.2\%) will not. Furthermore, 24 midwives (49\%) disagreed that the KMC provided should use special outfit, while the other 12 (24.5\%) agreed. The majority of them argued that temperature monitoring of neonates during KMC is unnecessary, while the other keep monitoring the temperature.

Study result showed that attitude varible on conducting KMC for premature neonates had lowest value of 10 and highest value of 40. Normality test using Shapiro-wilk showed significant value of $0.005 \quad(<0.05)$, which means the data were not normally distributed. Therefore, the cut-off point for dividing attitude category of the midwives was median value of 30. Positive and negative category were given if the value $>30$ and $<30$, respectively.

According to table 3, from 49 midwives, more than $50 \%$ of them (27 midwives, $55.1 \%$ ) had positive attitude or was supportive of the implementation of KMC, while the others (22 midwives, 44.9\%) had negative attitude. Categorization of attitude used median because of its non-normal distribution. In this study, factors that influenced the attitude, such as personal exence, necessary other people influence, printed mass media, electronic mass media, educational organization, religion organization, social organization, and emotional condition were not studied. 
Table 3. Distribution of Attitude Categories of Midwives on KMC for Premature Neonates in Batang Primary Health Care, Batang Subdistrict, Batang, Regency

\begin{tabular}{lll}
\hline Attitude & Frequency & Percentage (\%) \\
\hline Negative & 22 & 44.9 \\
Positive & 27 & 55.1 \\
\hline Total & 49 & 100.0 \\
\hline
\end{tabular}

Source: Primary Data, 2015

Table 4. Cross Tabulation between Knowledge and Attitudes of Midwives for KMC in Premature Baby at Community Health Service in Batang Subdistrict Batang Regency

\begin{tabular}{llllll}
\hline & & \multicolumn{2}{l}{ Attitudes Category } & \multirow{2}{*}{$\rho$ value } & \multirow{2}{*}{ Rho } \\
\cline { 3 - 4 } & & Negative & Positive & & \\
Knowledge & 10 & 1 & & \\
Category & Sufficient & $60.9 \%$ & $9.1 \%$ & & \\
& & $100 \%$ & 0 & 0.000 & \multirow{2}{*}{0.696} \\
& Good & 6 & 26 & & \\
& & $18.8 \%$ & $81.2 \%$ & & \\
\hline Total & & 22 & 27 & & \\
\hline
\end{tabular}

Source: Primary Data, 2015

Therefore, the factors that affected the negative or positive attitude were still poorly understood.

According to table 4, from 49 lowknowledge midwifes, there were 10 midwives who had negative attitudes (90.9\%) compared to just 1 midwife with positive attitude (9.1\%). All 6 sufficient-knowledge midwives (100\%), had negative attitudes, whereas 26 goodknowledge midwives (81.2\%) had positive attitudes, more than 6 midwives (18.8\%) who had negative attitude.

There was a strong relationship between midwives' knowledge and attitudes toward $\mathrm{KMC}$ in premature baby at Batang Regency with $p$ value $0.000(<0.05)$ using Spearman's Rho' test, which resulted in Ho being rejected, and the correlation coefficient (Rho) was 0.696.

Knowledge or cognition was a dominant factor in developing someone's behavior (overt behavior). The attitudes are not inherited, and are also formed and learned while dealing with the objects. It can change if there are specific conditions which ease someone's attitudes. The attitudes always have a relationship with objects and those can be a certain thing or a collection of certain things. It also have motivation and feeling aspects, which differ each person's attitude and knowledge. Usually, the higher the educational status, the easier to obtain information, which will lead to better knowledge (Notoatmodjo, 2010).

Midwife, a profession with minimum education of Diploma III (Decree of Indonesian Ministry of Health HK.1464/2010), will have easier access to information and hence better its knowledge. Our results showed that there were 10 from 11 low-knowledge midwives who had negative attitudes (90.9\%), all 6 sufficientknowledge midwives also had negative attitudes (100\%), and 26 of 32 good-knowledge midwives had positive attitudes (81.2\%).

The correlation between knowledge and attitudes is becoming interesting. Person with low knowledge will tend to behave negatively, and the good-knowledge persons behave positively. There is a certain place where lowknowledge people have positive attitudes, and vice versa, also there is a grey area where sufficient-knowledge people have negative attitudes. This correlational concept proves that the factors influencing attitudes are never singular, it is a variation of individual emotional experience, the influence of individual important person, socio-cultural background, mass media, and religion factor. Individual attitudes are influenced by cognitive, affective, 
and conative aspects. It is not only affected by the objects situation being faced, but also past experience, recent situation, and future hope.

The important factor of determining whole individual attitudes is knowledge. Knowledge of health workers (midwife) will affects client's (mother) knowledge and forms trust that will provide her perspective to prepare and carry out the management according to the guidence from health workers (Ta'adi, 2016).

According to Green theory, attitudes are factors that strengthen the development of behavior in midwife. This includes communication, self confidence, and interpersonal relationships. Midwifery care competency is an inseperable variable with knowledge and skill. When the midwife only uses skill and knowledge without her feeling, it will cause negative perception from the client (mother) to herself and also lower mother's behavior in obeying the instruction/suggestion (Pangesti, 2012).

Indeed, there is a difference in knowledge, attitudes, and motivation in midwifery practice (in neonatal asphyxia, premature, and low birthweight baby) between civil servant and temporary employee midwife. Civil servant midwife have better knowledge, attitudes, and motivation than temporary employee ones. This is similar with Herzberg that stated the influence of maintenance factors, such as fee, working condition, expectation and prospect of occupation affect a person's performance (Hartono, 2013).

There is also a difference regarding midwife working duration in management of low birthweight premature baby. It have good correlation, longer duration have better management than fewer ones (Pujiastuti, 2013). Achievement and acknowledgment of her work are related with midwife competency, including knowledge and attitudes in her task performance. Well-arranged achievement system will increase midwife competency (Pujiastuti, 2013).

Counseling, for knowledge dissemination, is one of many ways to increase knowledge. Knowledge giving influenced someone to behave better. Higher knowledge affects individual attitudes and changing behavior. Musfiroh (2014), stated that there were 3 components of complete attitudes development, there are belief, emotional life, and tendency to act.

Kangaroo mother care have significant effects toward increasing outcome of low birthweight because of regular and timely breastmilk administration frequency, baby sucking reflex will always be trained in response to thrist condition by looking at mother's nipple, and direct body contact to give the baby temperature stability from hypothermia risk. This condition will stabilize physiological function of the baby to help in body metabolism (Silvia, 2015).

Those previous study results was strengthten by a result which stated there was a significant difference in body temperature, heart rate, oxygen saturation in premature baby before and after kangaroo mother care in the first, second, and third day (Syamsu, 2013).

Regarding the effect of KMC in low birthweight, we can see from Astuti (2015), that there was significant result of baby weight incremental increase in 28 samples using paired t-test with pretest experiment mean of 2285.71 gram and post-test experiment mean of 3543.21 gram, so the increase was 1257.50 gram.

Other study of KMC influence toward physiological body functions was that there was body temperature increase at first day as much $0.23^{\circ} \mathrm{C}$, second day was $0.27^{\circ} \mathrm{C}$, and third day was $0.30^{\circ} \mathrm{C}$. Influence toward heart rate in first day was 2.88 beats per minute (bpm), second day was $2.00 \mathrm{bpm}$, and third day $1.13 \mathrm{bpm}$. Influence in oxygen saturation at first day was $0.56 \%$, second day was $0.50 \%$, and third day was $44 \%$ (Deswita, 2011).

In implementation of $\mathrm{KMC}$ and its influence in hypothermia, we found that bad KMC resulted in higher risk of hypothermia in baby, while good KMC will lower risk of hypothermia. The role of health workers, especially midwife, is important in this condition with good communication, information, and education. Therefore, it is necessary to midwife to have good, positive, and right knowledge and attitudes (Nurlaila, 2015).

We can interprete the importance of knowledge and attitude of midwife in socializing KMC for mother with low birthweight premature baby. From the study about effectivity 
of KMC in low birthweght improvement, it was necessary to perform continual socialization of $\mathrm{KMC}$, and also supervise and monitor its implementation (Heraswati, 2013). Fatkhiyah (2015), training for midwife and continual supervision from the authority, like Health Office, is needed to maintain obedience of the midwife to do her job, in order to increasing midwifery nursing quality.

\section{Conclusions}

From 49 respondents (midwives), 32 midwives had good knowledge about KMC in premature baby $(65.3 \%)$ and 27 midwives (55.1\%) had positive attitudes or supporting of $\mathrm{KMC}$ in premature baby.

There were 10 low-knowledge midwives who have negative attitudes (90.3\%), compared to only 1 who had positive attitude (9.1\%). Six midwives had sufficient knowledge (12.2\%) and all of them have negative attitudes $(100 \%)$, whereas there were $26(81.2 \%)$ goodknowledge midwives, higher than who had negative attitudes that is 6 midwives $(18.8 \%)$.

We found $p$ value of $0.000<0.05$ and correlation coefficient (Rho) 0.696 using Spearman's Rho test. It means there is a strong relationship between knowledge and attitude in implementing KMC of midwife for premature baby in Batang Community Health Center.

We hoped that the authority (Health Office and Community Health Center) implement steps to increase knowledge and attitude of KMC, such as training, seminar, workshop, in house training, or continual education for midwife, especially in working area of Community Health Center of Batang Subdistrict. We acknowledged Health Office of Batang Regency, Community Health Center of Batang Subdistrict, Indonesian Midwives Association Branch Batang, and all parties who have facilitated this study.

\section{References}

Astuti,D.P; Mutoharoh,S. 2015. Pengaruh Penerapam Metode Kanguru dengan Peningkatan Berat Badan Bayi Lahir Rendah di RS Muhammadiyah Gombong. Jurnal Involusi Kebidanan, 5 (9): 65-78.

Departemen Kesehatan RI, 2014, Profil Kesehatan Indonesia Tahun 2014.
Deswita ; Besral; Rustina Y. 2011. The Influences of Kangaroo Care Method on Physiological Response of Premature Infants. Jurnal Kesehatan Masyarakat Nasional, 5 (5): 227233.

Fatkhiyah, N. 2015. Motivasi, Kualitas dan Kepatuhan Bidan dalam Mendeteksi Preeklamsia. Jurnal Kemas, 10 (2): 195-202.

Hartono, M. 2013. Analisis Perbedaan Praktik dalam Penatalaksanaan Neonatal Asfiksia antara Bidan Desa PNS dan PTT di Batang. Jurnal Mersi, 4 (2): 15-20.

Heraswati, Rahayu, S. 2013. Efektifitas Perawatan Metode Kanguru Intermitten dalam Peningkatan Berat Badan Bayi Berat Lahir Rendah di RSUD Tugurejo Semarang . Jurnal Kebidanan, 2 (4): 10-15.

Musfiroh,M, 2014. Penyuluhan terhadap Sikap Ibu dalam Memberikan Toilet Training pada Anak. Jurnal Kemas, 9 (2): 157-166.

Notoatmodjo, Soekidjo. 2010. Metode Penelitian Kesehatan. Jakarta : Rineka Cipta.

Nurlaila; Shufiah, R. 2015. Hubungan Pelaksanaan Perawatan Metode Kanguru dengan Kejadian Hipotermi pada Bayi Berat Lahir Rendah. Jurnal Husada Mahakam, 3 (9): 466-472.

Pangesti,W.D ; Shahib,N. 2012. Hubungan Kompetensi (Pengetahuan, Sikap, dan Keterampilan) Bidan dengan Perilaku Ibu Hamil dalam Asuhan Antenatal (Studi Eksploratif di Kabupaten Banjarnegara). Jurnal Medisains, 10 (1): 21-29.

Pujiastuti, T. 2013. Faktor-Faktor yang Berhubungan dengan Penatalaksanaan BBLR tanpa Asfiksia oleh Bidan di Puskesmas Magelang. Jurnal Link, 9 (2): 588-595.

Puspitaningtyas, Astuti N, 2013. Gambaran Sikap Tenaga Kesehatan dan Pelaksanaan Metode Kanguru pada Bayi Berat Lahir Rendah di Ruang Perinatologi RSUD dr. Soeprapto Cepu. Jurnal Kebidanan, 1 (1): 27-38.

Silvia, Putri Y.L. 2015. Pengaruh Metode Kanguru terhadap Perubahan Barat Badan Bayi Lahir Rendah. Jurnal Ipteks Terapan, 9 (1): 11-19.

Syamsu, A.F. 2013. Pengaruh Perawatan Metode Kanguru terhadap Fungsi Fisiologis bayi Prematur dan Kepercayaan Diri Ibu dalam Merawat Bayi. Jurnal Keperawatan Soedirman, 8 (3): 163-175.

Tảadi, Amirudin Z, 2016. Hubungan Pengetahuan dengan Sikap Ibu dalam P4K di Wilayah Puskesmas Bendan Kota Pekalongan. Jurnal Litbang Kota Pekalongan, 10 (2): 22-29. 